\title{
Karakterisasi biokimia bakteri endofit akar terung sebagai pemacu pertumbuhan tanaman dan pengendali penyakit layu bakteri in planta
}

\author{
Biochemistry characterization of endophytic bacteria from eggplant root and their \\ potential to control bacterial wilt in planta
}

\author{
Larasati Puspita Saridewi ${ }^{*}$, Nur Prihatiningsih ${ }^{2}$, dan Heru Adi Djatmiko ${ }^{2}$ \\ Fakultas Pertanian, Universitas Jenderal Soedirman. Purwokerto, Jawa Tengah
}

\section{INFORMASI ARTIKEL}

\author{
*Korespondensi: \\ Larasati Puspita Saridewi \\ laras.puspita12@gmail.com \\ Informasi proses: \\ Received: 12 Desember 2019 \\ Accepted: 3 Januari 2020 \\ Published: 6 Januari 2020
}

Cara sitasi: Saridewi LP, Prihatiningsih N, Djatmiko HA. 2020. Karakterisasi biokimia bakteri endofit akar terung sebagai pemacu pertumbuhan tanaman dan pengendali penyakit layu bakteri in planta. Jurnal Proteksi Tanaman Tropis 1(1): 1-8

DOI:

\begin{abstract}
An important disease in eggplant is bacterial wilting caused by Ralstonia solanacearum. The aim of this research is to characterize the biochemical endophytic bacteria isolated from eggplant root (BEAT) and as an agent for promoting plant growth and controlling bacterial wilt disease in planta. This research was conducted at the Plant Protection Laboratory and screen house of the Faculty of Agriculture, Jenderal Soedirman University, Purwokerto. This research was conducted descriptively to test the biochemical character of BEAT and used a Complete Randomized Block Design (RCBD) in the in planta test with 4 treatments, 6 replications and 3 plants each treatment, so that 72 plants were tested. The treatment consisted of control (without endophytic bacteria) and 3 BEAT isolates. The results showed that the endophytic bacterium AKc isolate had the ability as a bacterium to promote plant growth by producing IAA phytohormones, phosphate solvents, enzymes producing proteases, cellulase, amylase, chitinase, and HCN, as well as increasing the root volume and fresh weight of plants respectively by $40,42 \%$ and $31 \%$, suppressing the disease intensity by $33.33 \%$ and able to suppress bacterial wilting the best on the AUDPC value that is $47.32 \%$-day.
\end{abstract}

Keywords: Endophytic bacteria; eggplant root; bacterial wilt; Ralstonia solanacearum

\section{Pendahuluan}

Tanaman terung (Solanum melongena L.) termasuk tanaman sayuran famili Solanaceae. Menurut Setiawati et al. (2007), tanaman terung sesuai ditanam di dataran rendah hingga dataran tinggi dengan $\mathrm{pH}$ tanah 5-6. Tanaman terung merupakan tanaman semak atau perdu dengan tinggi berkisar antara 60-240 $\mathrm{cm}$. Suhu yang tepat untuk tanaman terung berkisar antara $22-30^{\circ} \mathrm{C}$ dengan sedikit perbedaan antara suhu siang hari dan malam hari.

Peningkatnya kesadaran masyarakat akan pentingnya mengkonsumsi makanan sehat salah satunya adalah terung, setiap $100 \mathrm{~g}$ terung mengandung 26 kalori, $1 \mathrm{~g}$ protein $0,2 \mathrm{~g}$ hidrat arang, $25 \mathrm{IU}$ vitamin $\mathrm{A}, 0,06 \mathrm{~g}$ vitamin $\mathrm{B}$, serta $5 \mathrm{~g}$ vitamin $\mathrm{C}$ (Sunarjono et al. 2003). Konsumsi terung per tahun mengalami penurunan pada tahun 2017 dan 2018 sebesar 0,157 dan 0,043. Produksi terung di Indonesia mengalami peningkatan pada tahun 2014 sebesar 
11.407 ton. Akan tetapi, produksi terung mengalami penurunan hingga tahun 2016 dan kembali meningkat pada tahun 2017 sebesar 25.694 ton (BPS Jawa Tengah 2017). Produksi terung yang berfluktuasi setiap tahun salah satunya dipengaruhi oleh serangan hama dan patogen.

Salah satu penyakit penting pada tanaman terung adalah layu bakteri yang disebabkan oleh Ralstonia solanacearum. Hayward (1991) menyatakan bahwa $R$. solanacearum merupakan patogen tular tanah penting yang menyebabkan layu bakteri. Jangkauan inang dari patogen ini sangat luas yaitu lebih dari 200 spesies tanaman dari 50 famili (Hayward 2000). Serangan $R$. solanacearum dapat menyebabkan tanaman layu hingga kematian tanaman, sehingga menyebabkan kerugian hasil mencapai 50-100\% (Prihatiningsih and Djatmiko 2015).

Menurut Ramesh and Phadke (2012), perbedaan strain pada $R$. solanacearum mengakibatkan pengelolaan layu bakteri pada terung dan tanaman lainnya menjadi sulit. Selain itu juga disebabkan oleh kemampuan $R$. solanacearum untuk bertahan pada kondisi tanah yang buruk, inang yang bervariasi dan mekanisme menyerang inang yang efisien. Pengendalian yang dilakukan terhadap $R$. solanacearum biasanya menggunakan bakterisida sintetik, akan tetapi penggunaan yang berlebih dalam jangka waktu panjang dapat menyebabkan patogen menjadi resisten. Oleh karena itu perlu adanya pengendalian penyakit yang ramah lingkungan (Dewi et al. 2014). Ramesh et al. (2009), menyatakan koloni bakteri endofit memiliki kedudukan yang sesuai dengan patogen tanaman, terutama patogen layu pembuluh vaskular, yang mungkin dapat digunakan sebagai kandidat potensial sebagai agens hayati. Bakteri endofit hidup dalam jaringan tanaman dan tidak menyebabkan kerusakan substansial, tidak mendapatkan keuntungan ataupun menimbulkan gejala penyakit pada tanaman, sehingga berpotensi untuk dimanfaatkan sebagai agens pengendali penyakit layu bakteri (Reinhold-Hurek and Hurek 2011).

Kemampuan bakteri endofit sebagai pemacu pertumbuhan tanaman dan agens biokontrol terhadap penyakit layu bakteri dilaporkan Achari and Ramesh (2014), bakteri endofit bersifat antagonis terhadap $R$. solanacearum berdasarkan uji antagonis in vitro. Bakteri endofit tersebut mampu menghasilkan senyawa volatil dan senyawa penghambat, yaitu, $\mathrm{HCN}$, amonium dan acetoin, serta siderofor. Penelitian ini bertujuan untuk mengarakter bakteri endofit akar terung (BEAT) secara biokimia dan sebagai agens pemacu pertumbuhan tanaman serta pengendali penyakit layu bakteri in planta.

\section{Metode penelitian}

\section{Waktu dan Tempat Penelitian}

Penelitian ini dilaksanakan di Laboratorium Perlindungan Tanaman dan screen house Fakultas Pertanian Universitas Jenderal Soedirman, Purwokerto, Kabupaten Banyumas. Pelaksanaan penelitian dimulai pada bulan Mei 2018 sampai dengan Maret 2019.

\section{Karakterisasi BEAT sebagai Plant Growth Promoting Endophytic bacteria (PGPE).}

Uji penghasil Indole Acetic Acid (IAA). Strain antagonis diuji kemampuannya menghasilkan fitohormon IAA secara kualitatif menggunakan reagen Salkowski $\left(150 \mathrm{~mL} \mathrm{H} \mathrm{H}_{4} ; 250 \mathrm{~mL}\right.$ akuades; 7,5 mL $\mathrm{FeCl}_{3} \cdot 6 \mathrm{H}_{2} \mathrm{O}$ ) (Wahyudi et al. 2009). Isolat bakteri goreskan pada medium NA yang mengandung triptofan $100 \mathrm{mg} \mathrm{L}^{-1}$ untuk selanjutnya diuji dengan cara ditetesi reagen Salkowski. Hasil positif ditunjukkan dengan perubahan warna menjadi merah muda pada isolat setelah diinkubasi di tempat gelap selama 30 menit.

Uji pelarut fosfat. Strain antagonis diuji sebagai pelarut fosfat. Semua strain diinokulasi pada medium Pikovskaya. Diinkubasi pada suhu $28^{\circ} \mathrm{C}$ selama 48 jam. Zona bening di sekitar pertumbuhan koloni bakteri menunjukkan sebagai pelarut fosfat (Achari and Ramesh 2014).

Uji penghasil protease. Pengujian aktivitas proteolitik secara kualitatif dilakukan dengan menumbuhkan isolat bakteri endofit pada cawan petri yang berisi medium skim milk agar (SMA), lalu diinkubasi selama 48 jam. Isolat yang mampu meng-hasilkan enzim protease mampu menghasilkan zona bening (Dewi et al. 2016).

Uji penghasil selulase. Isolat bakteri yang berupa supernatan diinokulasi pada medium carboxy methyl celluase (CMC) menggunakan metode paper disk dan diinkubasi pada suhu $37^{\circ} \mathrm{C}$ selama 48 jam. Pengujian aktivitas selulotik dilakukan dengan metode Congo Red. Larutan Congo red (0,1\% w/v) dituang pada kultur dan dibiarkan selama 15 menit. Larutan dibuang dan dibilas menggunakan $\mathrm{NaCl}$ 0,2 M selama 15 menit sebanyak tiga kali. Kemudian diinkubasi pada suhu $4^{\circ} \mathrm{C}$ selama $48 \mathrm{jam}$. Zona bening yang terbentuk diamati (Murtiyaningsih and Hazmi 2017).

Uji penghasil amilase. Pengujian aktivitas amilolitik secara kualitatif dilakukan dengan cara menumbuhkan isolat bakteri endofit pada permukaan medium yeast peptone starch soluble (YPSs). Bakteri yang berumur 3 hari ditumbuhkan pada medium YPSs, kemudian diinkubasi pada suhu kamar selama 2 hari. Bakteri yang mampu mengasilkan enzim amilase terlihat dengan adanya zona bening di sekitar koloni setelah dituang larutan iodin (Soeka 2010). 
Uji penghasil kitinase. Bakteri endofit penghasil kitinase ditumbuhkan pada medium yang mengandung kitin dengan metode paper disk. Isolat bakteri kitinolitik dapat ditandai keberadaannya dengan mendegradasi medium agar kitin yang ditandai dengan adanya zona bening di sekitar koloni (Herdyastuti et al. 2009).

Uji penghasil senyawa sianida. Bakteri endofit dan bakteri rizosfer diinokulasi pada medium King's B cair yang mengandung 4,4 g/L glisin (Achari and Rames 2014), selanjutnya kertas saring dipotong berbentuk persegi $1 \times 1 \mathrm{~cm}$ dan dijenuhkan ke dalam larutan cyanide detection solution (CDS) yang mengandung $2 \mathrm{~g}$ asam pikrat dan $8 \mathrm{~g}$ natrium karbonat dalam $200 \mathrm{~mL}$ air steril (Pradana et al. 2016). Selanjutnya digojog dengan kecepatan 140 rpm selama 4 hari pada suhu ruang. Perubahan warna kertas saring dari kuning menjadi jingga kecokelatan diamati (Achari and Rames 2014).

\section{Uji in planta}

Pengujian in planta yang dilakukan di screenhouse Perlindungan Tanaman Fakultas Pertanian Universitas Jenderal Soedirman. Penelitian ini menggunakan Rancangan Acak Kelompok (RAK). Jumlah perlakuan yang diujikan sebanyak 4 dan 6 kali ulangan dengan 3 tanaman di setiap perlakuan, sehingga diperoleh 72 tanaman. Perlakuan yang diteliti adalah: Kontrol: tanpa formulasi bakteri endofit, AKa: isolat bakteri endofit akar a dalam formulasi ekstrak singkong, $\mathrm{AKb}$ : isolat bakteri endofit akar b dalam formulasi ekstrak singkong, AKc: isolat bakteri endofit akar c dalam formulasi ekstrak singkong.

Penyiapan medium tanam. Medium tanam yang digunakan adalah tanaman yang dicampur dengan pupuk kandang dengan perbandingan $1: 1$. Tanah yang telah dicampur merata dimasukkan ke dalam polybag dengan ukuran $40 \times 40 \mathrm{~cm}$. polybag yang sudah terisi tanah kemudian diletakkan pada lahan sesuai dengan denah rancangan yang telah dibuat.

Pembuatan dan aplikasi formulasi. Pembuatan formulasi dilakukan dengan mengambil 1 ose isolat bakteri dicampurkan ke dalam $100 \mathrm{~mL} \mathrm{NB}$ lalu di gojog dengan Orbital Shaker KBLee 3001 dengan kecepatan 150 rpm pada suhu kamar. $10 \mathrm{~mL}$ larutan NB yang berisi bakteri endofit dimasukkan ke dalam formula dengan komposisi singkong (200 g) + terasi $(4 \mathrm{~g})+$ glukosa (5 g) + air steril $1000 \mathrm{~mL}$. campuran didiamkan selama 3 hari. Perlakuan aplikasi bakteri endofit dilakukan sebanyak 5 kali dengan periode setiap 7 hari sekali selama 6 minggu. Masing-masing perlakuan sebanyak $100 \mathrm{~mL}$ untuk aplikasi.

Inokulasi $\boldsymbol{R}$. solanacearum. $R$. solanacearum diinokulasi dengan kerapatan populasi $10^{8} \mathrm{cfu} / \mathrm{mL}$, dengan cara sebanyak $80 \mathrm{~mL}$ suspensi bakteri disiramkan pada tanah dalam pot percobaan dan pada batang dengan cara disuntikkan pada saat tanaman berumur 14 hst (Rahmawanto et al. 2015). Pengamatan dilakukan setiap minggu selama 7 minggu.

\section{Variabel Pengamatan}

Intensitas penyakit. Intensitas penyakit diamati tiap minggu sampai fase vegetatif, dihitung dengan rumus (Rahardjo and Suhardi 2008):

$$
\mathrm{IP}=\frac{a}{b} \times 100 \%
$$

dengan IP= Intensitas penyakit; $a=j u m l a h$ tanaman layu; $b=$ jumlah tanaman yang diamati.

Laju Infeksi. Perhitungan laju infeksi menggunakan rumus yang dikemukakan oleh van der Plank (1963) sebagai berikut:

$$
X t=X o \cdot e^{r t}
$$

Dengan $\mathrm{Xt}=$ proporsi penyakit pada waktu $\mathrm{t} ; \mathrm{Xo}=$ proporsi penyakit pada awal pengamatan; $\mathrm{e}=$ konstanta logaritma (2,718); r= laju infeksi/laju perkembangan penyakit; $\mathrm{t}=$ waktu; Nilai $\mathrm{r}$ dihitung berdasarkan kriteria penyakit layu bakteri termasuk simple interest disease (SID), maka:

$$
r=\frac{2,3}{t}\left(\log \frac{1}{1-X_{t}}-\log \frac{1}{X o}\right)
$$

Nilai AUDPC. Area under the disease pathogen curve (AUDPC) dihitung dengan rumus (Jeger and Viljanen-Rollinson 2001):

$$
\text { AUDPC }=\sum_{i}^{n}\left(\frac{Y_{i}+Y_{i+i}}{2}\right)\left(t_{i+1}-t_{i}\right) \text {, }
$$

Keterangan : $\mathrm{Y}_{\mathrm{i}}=$ kejadian atau keparahan penyakit pada waktu ke-I; $Y_{i+1}=$ kejadian atau keparahan pada waktu ke-(i+1); $\mathrm{t}_{\mathrm{i}}=$ waktu pengamatan ke-i; $\mathrm{t}_{\mathrm{i}}+1=$ waktu pengamatan ke-(i+1); $n=$ jumlah pengamatan

Komponen pertumbuhan meliputi tinggi tanaman dan jumlah daun, diamati tiap 7 hari sekali selama 5 kali. Volume akar, bobot segar tanaman, bobot segar akar, panjang akar, bobot kering tanaman, bobot kering akar saat pengamatan terakhir.

\section{Analisis Data}

Data yang diperoleh dianalisis secara statistika dengan menggunakan analisis ragam ANOVA untuk mengetahui pengaruh perlakuan, maka dilakukan uji BNT pada taraf 5\%. Strain antagonis diuji kemampuannya menghasilkan fitohormon IAA secara kualitatif menggunakan reagen Salkowski $(150 \mathrm{~mL}$ $\mathrm{H}_{2} \mathrm{SO}_{4} ; 250 \mathrm{~mL}$ akuades; $7,5 \mathrm{~mL} \mathrm{FeCl} 3.6 \mathrm{H}_{2} \mathrm{O}$ ) (Wahyudi et al. 2009). Isolat bakteri goreskan pada medium NA yang mengandung triptofan $100 \mathrm{mg} \mathrm{L}^{-1}$ untuk selanjutnya diuji dengan cara ditetesi reagen Salkowski. Hasil positif ditunjukkan dengan perubahan 
warna menjadi merah muda pada isolat setelah diinkubasi di tempat gelap selama 30 menit.

\section{Hasil dan Pembahasan}

Hasil uji bakteri endofit penghasil fitohormon IAA (Gambar 1) menunjukkan bahwa terjadi perubahan warna menjadi merah muda setelah ditetesi reagen Salkowski. Isolat bakteri yang mengalami perubahan warna menjadi merah muda menunjukkan bahwa isolat bakteri mampu menghasilkan fitohormon IAA. Kovacs (2009) menyatakan bahwa isolat yang mampu menghasilkan IAA secara kualitatif akan berwarna merah muda karena adanya interaksi antara IAA dan Fe yang membentuk senyawa kompleks $\left[\mathrm{Fe}_{2}(\mathrm{OH})_{2}(\mathrm{IA})_{4}\right]$, IA merupakan indole-3-acetate. Interaksi tersebut terjadi pada suasana asam. Reaksi yang terbentuk merupakan reaksi kompleks dan reaksi redoks. Warna merah muda yang dihasilkan oleh bakteri semakin tinggi.

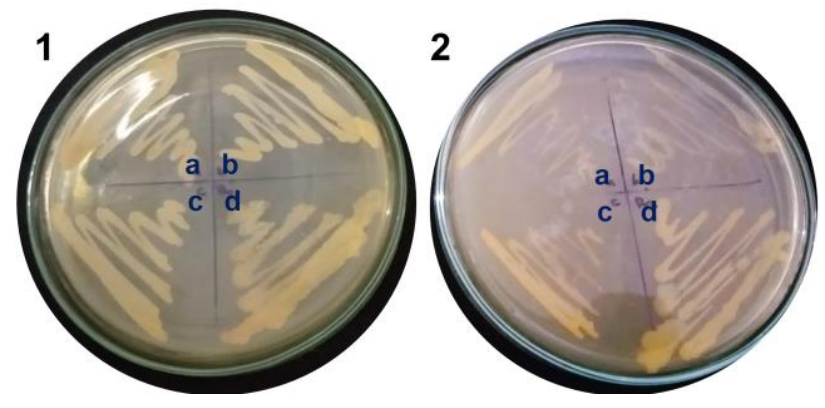

Gambar 1. Uji penghasil IAA bakteri endofit, (1) isolat bakteri endofit pada medium NA, (2) isolat bakteri endofit pada medium NA mengandung triptofan dan ditetesi reagen salkowski, (a) isolat bakteri $\mathrm{AKa},(\mathrm{b})$ isolat bakteri $\mathrm{AKb}$, (c) isolat bakteri $\mathrm{AKc},(\mathrm{d})$ isolat bakteri rizosfer.

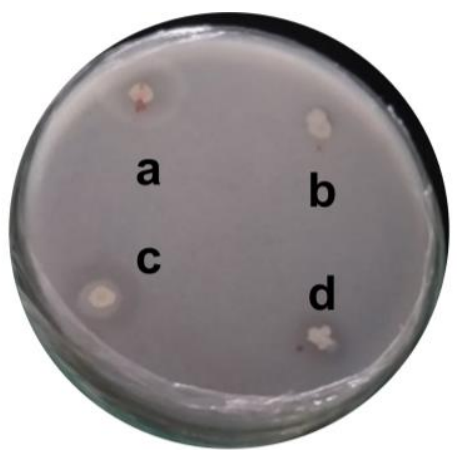

Gambar 2. Uji pelarut fosfat, (a) isolat bakteri endofit $\mathrm{AKa}$, (b) isolat bakteri endofit $\mathrm{AKb}$, (c) isolat bakteri endofit AKc, (d) isolat bakteri rizosfer.

Aktivitas proteolitik bakteri endofit pada medium agar yang mengandung susu skim diperlihatkan dengan adanya zona bening di sekitar koloni bakteri. Ketiga isolat bakteri endofit $\mathrm{AKa}, \mathrm{AKb}$, dan $\mathrm{AKc}$ menunjukkan bahwa ketiganya mampu menghasilkan zona bening pada medium SMA (Gambar 3). Zona bening menunjukkan bahwa protein dalam susu skim telah terdegradasi oleh protease yang dihasilkan oleh bakteri endofit.
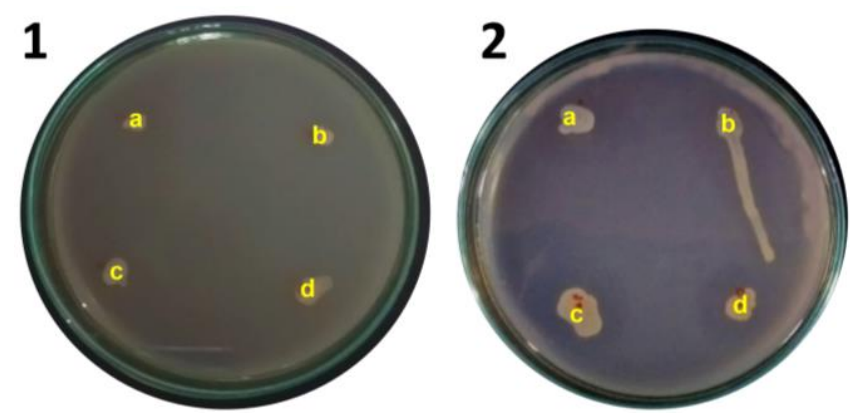

Gambar 3. Uji penghasil enzim protease, (1) pengamatan hari pertama, (2) pengamatan hari ke-3, (a) isolat bakteri endofit $\mathrm{AKa}$, (b) isolat bakteri endofit $\mathrm{AKb}$, (c) isolat bakteri endofit AKc, (d) isolat bakteri rizosfer.

Hasil uji menunjukkan bahwa isolat bakteri endofit mampu menghasilkan zona bening pada medium pikovskaya yang berwarna keruh (Gambar 2). Zona bening di sekeliling koloni mengindikasikan bahwa isolat mampu melarutkan fosfat kompleks. Terbentuknya zona bening pada agar terjadi akibat adanya pelarutan suspensi trikalsium fosfat $\left(\mathrm{Ca}_{3}\left[\mathrm{PO}_{4}\right]^{2}\right)$ (Alam et al. 2002). Mekanisme pelarutan fosfat bakteri endofit dikaitkan dengan kemampuannya dalam menghasilkan asam organik. Asam organik diketahui mampu menurunkan $\mathrm{pH}$ dan menyebabkan pelarutan fosfat (Islam et al. 2007).

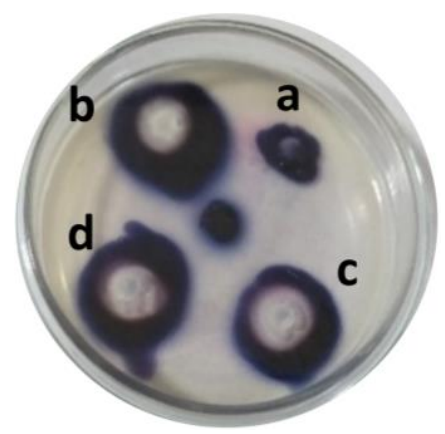

Gambar 4. Uji penghasil enzim amilase, (a) isolat bakteri endofit AKa, (b) isolat bakteri endofit $\mathrm{AKb}$, (c) isolat bakteri endofit AKc, (d) isolat bakteri rizosfer.

Aktivitas selulotik bakteri endofit penghasil selulase ditandai dengan perubahan warna pada medium CMC yang ditetesi $1 \%$ congo red dan dicuci menggunakan $\mathrm{NaCl} 1 \%$. Isolat AKa hanya mampu menghasilkan zona bening yang lebih sedikit jika dibandingkan dengan isolat $\mathrm{AKb}$ dan $\mathrm{AKc}$. Zona bening di sekitar bakteri menandakan bahwa bakteri mampu menghasilkan selulase yang dapat menghidrolisis selulosa menjadi lebih sederhana yaitu glukosa (Baharuddin et al. 2010). 
Aktivitas amilolitik bakteri endofit penghasil enzim amylase ditandai dengan adanya zona bening di sekitar bakteri pada medium selektif YPSs yang ditetesi dengan iodin. Berdasarkan hasil uji penghasil amylase bakteri AKa tidak menunjukkan adanya zona bening yang terbentuk, sehingga dapat disimpulkan bahwa bakteri tersebut tidak mampu menghasilkan enzim amilase (Gambar 4).

Isolat $\mathrm{AKb}$ dan $\mathrm{AKc}$ memiliki aktivitas amilolitik yang ditandai dengan terbentuknya zona bening di sekitar koloni yang telah ditetesi larutan iodin. Hal ini sejalan dengan pernyataan Soeka et al. (2015), zona bening yang terbentuk karena aktivitas enzim aamilase yang menghidrolisis pati terlarut, sehingga larutan pati di sekitar koloni bakteri terkonversi menjadi amilosa dan tidak bereaksi dengan larutan iodin.

Aktivitas bakteri kitinolik ditandai dengan terbentuknya zona bening di sekitar koloni bakteri pada medium selektif kitin. Hasil uji menunjukkan ketiga isolat mampu menghasilkan enzim kitinase yang ditandai dengan adanya zona bening di sekitar koloni bakteri. Hal ini sejalan dengan penelitian Suryadi et al. (2013) yang menyatakan zona bening terbetuk akibat enzim kitinase dikeluarkan dari sel bakteri untuk memecah makromolekul kitin menjadi molekul kitin yang lebih kecil. Gohel et al. (2006) menjelaskan bahwa aktivitas kitin secara kualitatif ditentukan oleh adanya zona bening di sekitar koloni bakteri yang tumbuh pada medium agar kitin.

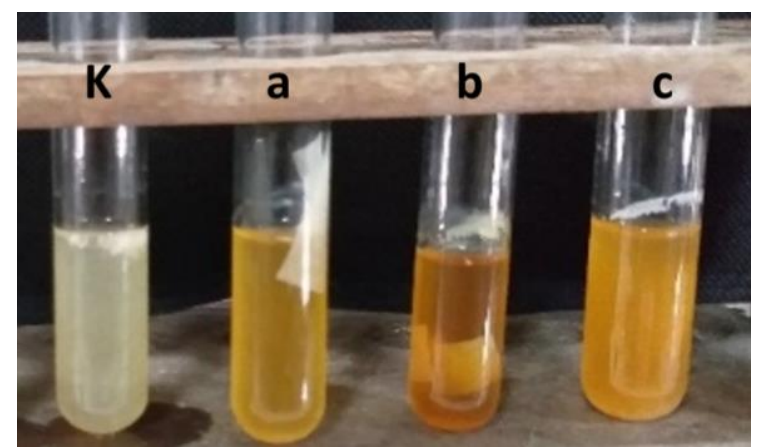

Gambar 5. Uji penghasil HCN, (k) kontrol (tidak menghasilkan $\mathrm{HCN}$ ), (a) isolat BEAT Aka penghasil $\mathrm{HCN}$, (b) isolat BEAT AKb, (c) isolat BEAT Akc penghasil HCN.

Hasil uji menunjukkan ketiga isolat bakteri endofit mampu menghasilkan senyawa sianida yang ditunjukkan dengan perubahan warna medium King's
B cair yang mengandung pepton dan glisin menjadi kuning kecoklatan hingga coklat setelah pemberian larutan CDS pada kertas saring. Hal ini sejalan dengan hasil penelitian Laili and Agustiyani (2016) yang menyatakan bahwa terdapat 7 bakteri yang menunjukkan kemampuannya dalam menghasilkan senyawa $\mathrm{HCN}$, dengan perubahan warna pada kertas saring dari kuning menjadi cokelat gelap (Gambar 5)

Peningkatan jumlah massa mikroba akan menyebabkan meningkatnya kandungan protein pada produk fermentasi. Bacillus sp. termasuk jenis bakteri saprofit yang mampu bertahan dan berkembang pada sisa-sisa bahan organik seperti limbah air singkong Tabel 1). Singkong mengandung energi 146 kalori, 1,2 g protein, 0,3 g lemak, 34,7 g karbohidrat, $33 \mathrm{mg}$ kalsium, $40 \mathrm{mg}$ fosfor, $0,7 \mathrm{mg}$ zat besi, $0,006 \mathrm{mg}$ vitamin $\mathrm{B} 1,30 \mathrm{mg}$ vitamin C, dan 62,5 g air (Darjanto dan Murdjati 1980).

Tabel 1. Populasi koloni bakteri endofit pada medium NB dan formulasi ekstrak singkong

\begin{tabular}{lcc}
\hline Isolat & $\begin{array}{c}\text { Kepadatan koloni } \\
\text { pada Medium NB } \\
(\mathrm{cfu} / \mathrm{ml})\end{array}$ & $\begin{array}{c}\text { Kepadatan koloni } \\
\text { pada formulasi } \\
\text { ekstrak singkong } \\
(\mathrm{cfu} / \mathrm{ml})\end{array}$ \\
\hline $\mathrm{AKa}$ & $600 \times 10^{8}$ & $90 \times 10^{9}$ \\
$\mathrm{Akb}$ & $40 \times 10^{8}$ & $0,13 \times 10^{9}$ \\
$\mathrm{Akc}$ & $70 \times 10^{8}$ & $140 \times 10^{9}$ \\
\hline
\end{tabular}

Hasil pengamatan (Tabel 2.) pada perlakuan bakteri endofit AK a-c mampu menunda terjadinya penyakit layu yang disebabkan oleh patogen $R$. solanacearum pada tanaman terung, hanya 2 hari. Masa inkubasi ini dipengaruhi oleh faktor di antaranya tanaman inang, lingkungan, dan patogen. Konsentrasi dan virulensi bakteri patogen, serta ketahanan tanaman berperan dalam menentukan berapa lama waktu yang dibutuhkan bakteri untuk menimbulkan gejala (Hersanti 2009).

Berdasarkan hasil analisis statistik (Tabel 2.) antara perlakuan bakteri endofit berbeda nyata dengan kontrol. Perlakuan AKc mampu menekan intensitas penyakit terbesar yaitu $53,84 \%$. Aplikasi bakteri endofit memiliki potensi dapat menekan perkembangan penyakit, hal ini ditunjukkan adanya perbedaan secara nyata pada analisis statistika. Perlakuan AKc termasuk dalam genus Bacillus sp. Hal ini sejalan dengan penelitian Prihatiningsih et al. (2015), B. subtillis tipe alami mampu memberikan efektifitas penekanan penyakit sampai dengan $64 \%$. Isolat AKc menunjukkan

Tabel 2. Masa inkubasi, intensitas penyakit, dan laju infeksi penyakit layu bakteri terung

\begin{tabular}{lccccc}
\hline Perlakuan & $\begin{array}{c}\text { Masa Inkubasi } \\
(\mathrm{hsi})^{*}\end{array}$ & $\begin{array}{c}\text { Intensitas Penyakit } \\
(\%)\end{array}$ & $\begin{array}{c}\text { Penekanan Penyakit } \\
(\%)\end{array}$ & $\begin{array}{c}\text { Laju Infeksi (r) } \\
(\text { unit/hari)* }\end{array}$ & AUDPC (\%-hari) \\
\hline Kontrol & 16 & $72.22 \mathrm{~b}$ & 0 & 0,097 & 270 \\
$\mathrm{AKa}$ & 18 & $38.88 \mathrm{a}$ & 46 & 0,046 & 155,5 \\
$\mathrm{AKb}$ & 18 & $44.44 \mathrm{a}$ & 38,5 & 0,047 & 160 \\
AKc & 18 & $33.33 \mathrm{a}$ & 53,84 & 0,035 & 142,2 \\
\hline Keterangan: angka yang dikuti oleh huruf yang sama pada kolom yang sama menunjukkan pengaruh tidak berbeda nyata pada uji
\end{tabular}

Keterangan: angka yang diikuti oleh huruf yang sama pada kolom yang sama menunjukkan pengaruh tidak berbeda nyata pada uji BNT dengan taraf kesalahan $5 \%$. Keterangan $\left(^{*}\right)$ : data tidak dianalisis. 
efikasi yang konsisten baik pada in vitro maupun in planta.

Berdasarkan Tabel 2. perlakuan kontrol memberikan laju infeksi tertinggi yaitu 0,097 unit/hari sedangkan laju infeksi terendah yaitu pada perlakuan $\mathrm{AKc}$ sebesar 0,035 unti/hari. Hal ini sesuai dengan Bustaman (2006) yang menyatakan bahwa laju infeksi penyakit layu bakteri yang disebabkan oleh $R$. solanacearum pada tanaman jahe dapat diturunkan oleh Bacillus sp., sehingga penyakit k layu bakteri tidak mengalami peningkatan.

Berdasarkan grafik nilai Area Under Disease Progress Currve (AUDPC) pada Gambar 6. tanaman terung yang diberikan perlakuan bakteri endofit memiliki nilai rendah dibandingkan dengan kontrol. Nilai AUDPC paling tinggi pada perlakuan kontrol (K), nilainya sebesar 270\%-hari, sedangkan nilai AUDPC terendah pada perlakuan AKc nilainya sebesar 142,2\%hari. Berdasarkan data tersebut perlakuan AKc merupakan bakteri endofit c yang mampu menekan penyakit layu bakteri paling baik yaitu 47,32\%. Hal ini sesuai dengan pernyataan Nuryani et al. (2011) bahwa semakin rendah nilai AUDPC, maka perlakuan yang diberikan semakin efektif dalam mengendalikan patogen.

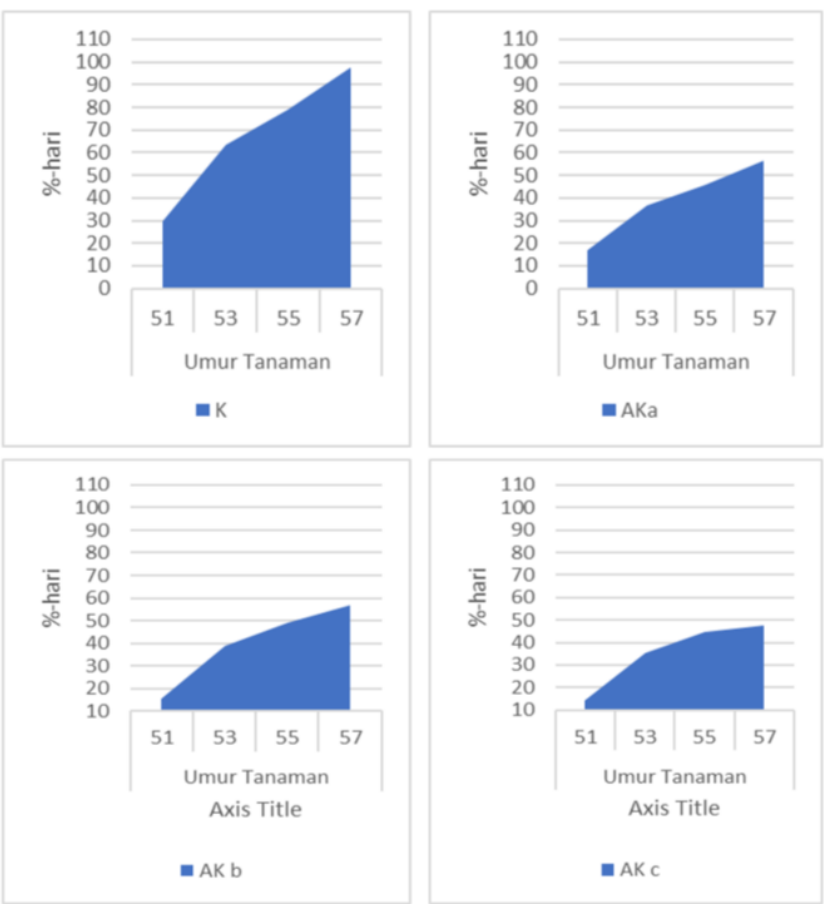

Gambar 6. AUDPC penyakit yang disebabkan oleh $R$. solanacearum pada tanaman terung.

Kemampuan bakteri endofit dalam menekan penyakit layu bakteri yang ditunjukkan dengan rendahnya nilai AUDPC dikarenakan kemampuan bakteri dalam menghasilkan senyawa metabolit sekunder salah satunya berupa HCN. Wandita et al. (2018) menyatakan bahwa adanya HCN pada jaringan tanaman yang diproduksi oleh bakteri endofit berperan sebagai biokontrol lingkungan yang berasal dari tanaman terhadap serangan gulma, penyakit atau nematoda.

Hasil analisis statistika, tinggi tanaman menunjukkan tidak berbeda nyata antara perlakuan isolat bakteri endofit AKa, AKb, AKc dengan kontrol (Tabel 3). Hal ini diduga karena rendahnya konsentrasi Ltriptofan dalam tanah yang dapat digunakan oleh bakteri endofit untuk membentuk auksin. Menurut Astuti (2008), adanya penambahan precursor Ltriptofan umumnya dapat menghasilkan konsentrasi IAA lebih tinggi. L-triptofan adalah asam amino aromatik yang mempunyai cincin Indole yang terikat pada gugus metilen dan terdapat tambahan atom nitrogen pada rantai samping. Hasil analisis statistika jumlah daun tidak berbeda nyata antara perlakuan bakteri endofit AKa, AKb, dan AKc dengan kontrol. Hal ini dapat terjadi karena bakteri endofit yang berada pada jaringan floem dengan kondisi kecukupan hara dalam pembentukan organ daun (Stoltfus et al. 1997). Sesuai dengan hal tersebut Ikhwan et al. (2016) menyatakan macam pemberian bakteri tidak berpengaruh nyata terhadap jumlah daun.

Hasil analisis statistika aplikasi bakteri endofit $\mathrm{AKa}, \mathrm{AKb}$, AKc tidak memberikan pengaruh yang nyata terhadap panjang akar hasil terpanjang pada perlakuan AKc sebesar 35,02 cm. Hal tersebut diduga karena pengaruh dari volume medium tanam memungkinkan terbatasnya unsur hara yang dapat terserap oleh akar tanaman dan ruang gerak dari tanaman. Hasil analisis statistika menunjukkan bahwa aplikasi bakteri endofi AKa, AKb, AKc memberikan pengaruh terhadap volume akar tanaman terung. Volume akar paling besar 40,42\% ditunjukkan oleh tanaman dengan aplikasi bakteri endofit AKc. Menurut Brimecombe et al. (2001), kolonisasi akar oleh bakteri terdiri atas empat tahap, yaitu: pergerakan bakteri menuju permukaan akar tanaman secara aktif (induksi

Tabel 3. Tinggi tanaman, jumlah daun, panjang akar, volume akar, bobot segar tanaman, bobot kering tanaman, bobot segar akar, bobot kering akar.

\begin{tabular}{|c|c|c|c|c|c|c|c|c|}
\hline Perlakuan & $\begin{array}{c}\text { Tinggi } \\
\text { Tanaman } \\
(\mathrm{cm})\end{array}$ & $\begin{array}{c}\text { Jumlah } \\
\text { Daun (helai) }\end{array}$ & $\begin{array}{c}\text { Panjang } \\
\text { Akar }(\mathrm{cm})\end{array}$ & $\begin{array}{c}\text { Volume } \\
\text { Akar (mL) }\end{array}$ & $\begin{array}{l}\text { Bobot Segar } \\
\text { Tanaman (g) }\end{array}$ & $\begin{array}{l}\text { Bobot Kering } \\
\text { Tanaman (g) }\end{array}$ & $\begin{array}{c}\text { Bobot } \\
\text { segar } \\
\text { Akar (g) }\end{array}$ & $\begin{array}{c}\text { Bobot } \\
\text { Kering Akar } \\
\text { (g) }\end{array}$ \\
\hline Kontrol & $25,77 \mathrm{a}$ & $14,38 \mathrm{ab}$ & $29,47 a$ & $9,27 \mathrm{a}$ & $9,77 \mathrm{a}$ & $4,59 \mathrm{ab}$ & $4,62 \mathrm{~b}$ & $2,51 \mathrm{bc}$ \\
\hline $\mathrm{AKa}$ & $28,11 \mathrm{a}$ & $13,61 \mathrm{ab}$ & $31,16 \mathrm{a}$ & $15,00 \mathrm{a}$ & $11,20 \mathrm{a}$ & $4,26 \mathrm{a}$ & $4,65 \mathrm{~b}$ & $2,32 \mathrm{ab}$ \\
\hline $\mathrm{AKb}$ & $28,91 \mathrm{a}$ & $12,77 \mathrm{a}$ & $29,47 \mathrm{a}$ & $13,89 \mathrm{a}$ & $10,50 \mathrm{a}$ & $3,90 \mathrm{a}$ & $3,55 \mathrm{a}$ & $2,13 \mathrm{a}$ \\
\hline $\mathrm{AKc}$ & $30,22 \mathrm{a}$ & $16,77 \mathrm{~b}$ & $35,02 \mathrm{a}$ & $25,89 \mathrm{~b}$ & $14,20 \mathrm{~b}$ & $5,37 \mathrm{~b}$ & $5,33 \mathrm{~b}$ & $2,85 \mathrm{c}$ \\
\hline
\end{tabular}

Keterangan: angka diikuti huruf pada kolom sama menunjukkan tidak berbeda nyata pada BNT dengan taraf kesalahan $5 \%$ 
spesifik terhadap aktifitas flagella secara kemotaksis), penempelan pada akar, pelekatan (menempel lebih kuat) dan induksi ekspresi gen.

Hasil analisis statistika pengaruh perlakuan terhadap bobot segar tanaman menunjukkan hasil perlakuan $\mathrm{AKa}, \mathrm{AKb}, \mathrm{AKc}$ berbeda nyata dibandingkan dengan perlakuan kontrol. Akan tetapi tidak berbeda nyata antar-perlakuan bakteri endofit. Perlakuan AKc mampu meningkatkan bobot segar tanaman sebesar $31 \%$. Hal ini diduga karena adanya peranan bakteri endofit dalam melarutkan fosfat. Menurut Herman and Pranowo (2013) bakteri pelarut fosfat berperan dalam menyediakan unsur hara $\mathrm{P}$ untuk diserap akar. Hasil analisis statistika menunjukkan bobot segar akar tidak berbeda antara perlakuan dengan kontrol. Pertumbuhan bobot basah tanaman ini berkaitan erat dengan panjang akar. Menurut Gardner et al. (1991) bobot basah akar mengacu pada fungsi utama akar sebagai organ vegetatif utama yang memasok air, mineral dan bahan penting untuk pertumbuhan tanaman.

Hasil analisis statistika terhadap bobot kering tanaman dan akar menunjukkan hasil perlakuan AKa, $\mathrm{AKb}, \mathrm{AKc}$ tidak berbeda nyata dibandingkan dengan perlakuan kontrol. Hal ini sesuai dengan penelitian Tinendung et al. (2014) bahwa pemberian formulasi Bacillus sp. berpengaruh tidak nyata pada bobot kering tanaman padi.

Bakteri endofit isolat AKc memiliki kemampuan sebagai pemacu pertumbuhan tanaman dengan menghasilkan fitohormon IAA, pelarut fosfat, penghasil enzim protease, selulase, amilase, kitinase, dan $\mathrm{HCN}$. Bakteri endofit meningkatkan volume akar dan bobot segar tanaman masing-masing sebesar $40,42 \%$ dan $31 \%$, penekanan intensitas penyakit layu bakteri sebesar 33,33\% dan nilai AUDPC yaitu 47,32\%-hari. Perlu dilakukan penelitian lebih lanjut untuk mengetahui secara kuantitatif IAA, pelarut fosfat, enzim, dan $\mathrm{HCN}$ yang dihasilkan serta mengetahui jenis bakteri endofit ke tingkat spesies dan konsentrasi formulasi yang tepat digunakan untuk aplikasi bakteri endofit.

\section{Pernyataan tidak ada konfik kepentingan}

Semua penulis artikel ini menyatakaan bahwa tidak ada konflik kepentingan terkait penelitian dan hasil penelitian ini.

\section{DAFTAR PUSTAKA}

Achari GA, Ramesh R. 2014. Diversity, biocontrol, and plant growth promoting abilities of xylem residing bacteria from solanaceous crops. International Journal Microbiology. 2014: 296521. https://doi.org/10.1155/ 2014/296521.

Alam S, Ayub N, Rashid M. 2002. In vitro solubilisation of inorganic phosphate by phosphate solubilizing microorganism (PSM) from Maize rhizosphaere. International Journal of Agriculte and Biology. 4 (4): 454-458.
Astuti RP. 2008. Rizobakteria Bacillus sp. Asal Tanah Rizosfer Kedelai yang Berpotensi sebagai Pemacu Pertumbuhan Tanaman. [Tesis]. Institut Pertanian Bogor. Bogor.

Badan Pusat Statistik. 2017. Statistik Tanaman Sayuran dan Buah-buahan Semusim Indonesia. Badan Pusat Statistik Republik Indonesia, Jakarta.

Baharuddin AS, Razak MNA, Hock LS, Ahmad MN, Abd-Aziz S, Rahman NAA, Shah UKM, Hassan MA, Sakai K, Shirai Y. 2010. Isolation and characterization of thermophilic callulaseproducing bacteria from empty fruit vunches-palm oli mill effluent compost. American Journal of Applied Sciences. 7 (1): 56-62.

Brimecombe MJ, Leij FA, de Lynch JM. 2001. The effect of root exudates on rhizosphere microbial populations. In: Pinton $\mathrm{R}$, Varanini Z, Nannipieri P. Editors. The Rhizosphere: Biochemistry and organic substances at the soil-plant interface. Marcel Dekker, Inc. New York.

Bustamam H. 2006. Seleksi mikroba rizosfer antagonis terhadap bakteri Ralstonia solanacearum penyebab penyakit layu bakteri pada tanaman jahe di lahan tertindas. Jurnal IlmuIlmu Pertanian Indonesia. 8 (1):12-18.

Darjanto, Murdjati. 1980. Khasiat, Racun dan Masakan Ketela Pohon. Yayasan Dewi Sri. Bogor

Dewi MK, Ratnasari E, Trimulyono G. 2014. Aktivitas antibakteri ekstrak daun majapahit (Crescentia cujete) terhadap pertumbuhan bakteri Ralstonia solanacearum penyebab penyakit layu. Lentera Bio. 3 (1): 51-57.

Dewi TK, Suryanggono J, Agustiyani D. 2016. Isolasi dan uji aktivitas bakteri penghasil hormon tumbuh IAA (Indole-3Acetic Acid) dan bakteri perombak protein dari tanah pertanian tual, Maluku Tenggara. Prosiding Seminar Nasional Masyarakat Biodiversitas Indonesia. 2 (2): 271-276. doi: $10.13057 / \mathrm{psnmbi} / \mathrm{m} 020226$.

Gardner, Franklin P, dkk. 1991. Fisiologi Tanaman Budidaya Fisiologi Tanaman Budidaya. Universitas Indonesia. UI Press. Jakarta.

Gohel V, Singh A, Vimal M, Ashwini P, and Chhatpar HS. 2006. Bioprospecting and antifungal potential of chitinolytic microorganism. African Journal Biotechnol. 5(2):54-72.

Hayward AC. 1991. Biology and epidemiology of bacterial wilt caused by Pseudomonas solanacearum. Annu Rev Phytopathol 29: 65-87.

Hayward A.C. 2000. Ralstonia solanacearum. In: Lederberg, J. (Ed.), 2000. Encyclopedia of Microbiology, vol. 4. Academic Press. San Diego.

Herdyastuti N, Raharjo TJ, Mudasir, Matsjeh S. 2009. Kitinase dan mikroorganisme kitinolitik: isolasi, karakterisasi, dan manfaatnya. Indonesian Journal of Chemistry. 9 (1): 37-47.

Herman M, Pranowo D. 2013. Pengaruh mikroba pelarut fosfat terhadap pertumbuhan dan serapan hara $\mathrm{P}$ benih kakao (Theobroma cacao L.). Buletin RISTRI. 4 (2): 129-138.

Hersanti, Rupendi RT, Purnama A, Hanudin, Marwoto, Gunawan OS. 2009. Penapisan beberapa isolat Pseudomonas fluorescens, Bacillus subtilis, dan Trichoderma harzianum yang bersifat antagonistic terhadap Ralstonia solanacearum pada tanaman kentang. Jurnal Agrikultura. 20 (3): 198-203.

Ikhwan A, Sufianto, Detalia. 2016. Uji potensi berbagai formula bakteri endofitik sebagai pupuk hayati tiga varietas padi (Oriza sativa) lahan kering. Prosiding Seminar Nasional dan Gelar Produk (SeNasPro 2016), Universitas Muhamadiyah Malang, 17-18 Oktober 2016. [Malang].

Jeger M, Viljanen-Rollinson S. 2001. The use of area under the disease-progress curve (AUDPC) to assess quantitative 
disease resistance in crop cultivars. Theory Application Genetic. 102: 32-40.

Kovacs K. 2009. Applications of Mosssbauer Spectroscopy in Plant Physiology. Dissertation. ELTE Chemistry Doctoral School. ELTE Institute of Chemistry. Budapest.

Laili N, Agustiyani D. 2016. Karakterisasi dan uji aktivitas biokontrol bakteri endofit dari Lombok terhadap kapang patogen Fusarium oxysporum f.sp. lycopersici. Prosiding Seminar Nasional II Tahun 2016, Kerjasama Prodi Pendidikan Biologi FKIP dengan Pusat Studi Lingkungan dan Kependudukan (PSLK) Universitas Muhammadiyah Malang, 26 Maret 2016. [Indonesia]

Murtiyaningsih H, Hazmi M. 2017. Isolasi dan uji aktivitas enzim selulase pada bakteri selulolitik asal tanah sampah. Agritrop. 15 (2): 293-308.

Nuryani W, Yusuf ES, Djatnika I, Hanudin, Marwoto B. 2011. Pengendalian penyakit layu Fusarium pada Subang Gladiol dengan pengasapan dan biopestisida. Jurnal Hortikultura. 21 (1): 40-50.

Pradana AP, Munif A, Supramana. 2016. Bakteri endofit asal berbagai akar tanaman sebagai agens pengendali nematoda puru akar Meloidogyne incognita pada terung. Jurnal Fitopatologi Indonesia. 12 (3): 75-82.

Prihatiningsih N, Djatmiko HA. 2015. Karakter Bacillus subtilis B315 sebagai antibakteri Ralstonia solanacearum dan antijamur Colletotrichum sp. Prosiding Seminar Nasional PFI Komda Joglosemar. Universitas Gadjah Mada, Yogyakarta, 20 September 2014. [Indonesia]

Prihatiningsih N, Arwiyanto T, Hadisutrisno B, Widada J. 2015. Mekanisme antibiosis Bacillus subtilis B315 untuk pengendalian penyakit layu bakteri kentang. Jurnal HPT Tropika. 15 (1): 64-71.

Rahardjo IB, Suhardi. 2008. Insidensi dan intensitas serangan penyakit karat putih pada beberapa klon Krisan. Jurnal Hortikultura. 18 (3): 312-318.

Rahmawanto DG, Anton M, Luqman QA. 2015. Pengaruh faktor antibiotik kimia tanah terhadap supressifitas tanah dalam mengendalikan penyakit layu bakteri (Ralstonia solanacearum) pada tanaman toman (Lycopersicon esculentum Mill). Jurnal HPT. 3 (2):1-8.

Ramesh R, Phadke GS. 2012. Rhizosphere and endophytic bacteria for the suppression of eggplant wilt caused by Ralstonia solanacearum. Crop Protection. 37: 35-41.

Reinhold-Hurek B, Hurek T. 2011. Living inside plants: bacterial endophytes. Curr Opin Plant Biol 14: 435-443.

Setiawati W, Rini M, Gina AS, Tri H. 2007. Budidaya Tanaman Sayuran. Balai Penelitian Tanaman Sayuran. Pusat Penelitian dan Pengembangan Hortikultura. Badan Penelitian dan Pengembangan Pertanian, Jawa Barat
Soeka YS. 2010. Optimasi dan karakterisasi a-amilase dari isolat aktinomisetes yang berasal dari Kalimantan Timur. Berita Biologi. 10 (3): 361-367.

Soeka YS, Rahmansyah M, Sulistiani. 2015. Optimasi enzim aamilase dari Bacillus amyloliquefaciens $\mathrm{O}_{1}$ yang diinduksikan substrat dedak padi dan karboksimetilselulosa. Jurnal Biologi Indonesia. 11 (2): 259-266.

Stoltfus JR, So R. Malarvithi PP, Ladha JK, de Brujn FJ. 1997. Isolation of endhophytic bacteria from rice and assessment of their potential for supplying rice biologically fixed nitrogen. Plant Soil. 194: 25-36.

Sunarjono HA, Soetasad A, Muryanti S. 2003. Budidaya Terung Lokal dan Terung Jepang. Penebar Swadaya, Jakarta.

Suryadi Y. 2013. Efektivitas Pseudomonas fluorescens terhadap penyakit layu bakteri (Ralstonia solanacearum) pada tanaman kacang tanah. Jurnal HPT Tropika. 9 (2): 174-180.

Tinendung R, Puspita F, Yoseva S. 2014. Uji formulasi Bacillus sp. sebagai pemacu pertumbuhan tanaman padi sawah (Oriza sativa). Jurnal Online Mahasiswa Fakultas Pertanian Universitas Riau. 1(2): 1-15.

Ulfiyanti N, Zulaika E. 2015. Isolat Bacillus pelarut fosfat dari Kalimas Surabaya. Jurnal Sains dan Seni ITS. 4 (1): 1-3.

Van der Plank JE. 1963. Plant Disease: Epidemics and Control. Academic Press. New York.

Wandita RH, Pujiyanto S, Suprihadi A, Hastuti RD. 2018. Isolasi dan karakterisasi bakteri endofit pelarut fosfat dan peghasil hydrogen cyanide (HCN) dari tanaman bawang merah (Allium cepa L.). Bioma. 20 (1): 9-16.

Wahyudi AT, Panjaitan M, Rachmania N. 2009. Konstruksi mutan Pseudomonas sp. untuk meningkatkan produksi indole acetic acid (IAA) melalui mutagenesis dan transposon. Biosfera. 26 (3): 100-107. 